\title{
MODELING TOTAL-NITROGEN DYNAMICS DURING ELECTROCOAGULATION PROCESS WITH STAINLESS-STEEL ELECTRODES
}

Scientific paper/Znanstveni rad

Goran Lončar

(Received: 15 April 2018; accepted: 29 May 2018)

University of Zagreb, Faculty of Civil Engineering, Full Professor

Corresponding author: gloncar@grad.hr

Ivan Halkijević

University of Zagreb, Faculty of Civil Engineering, Assistant Professor

Hana Posavčić

University of Zagreb, Faculty of Civil Engineering, mag. ing. aedif.

Ivica Ban

University of Zagreb, Faculty of Civil Engineering, mag. ing. aedif.

\begin{abstract}
The efficiency of the electrocoagulation (EC) process for the removal of total $N(T N)$ is analyzed using a pilot device (reactor) with stainless-steel electrodes. Additionally, a three-dimensional (3D) numerical model for $\mathrm{TN}$ removal via the EC process is developed. The effects of the flow rate through the reactor and the initial $\mathrm{NaCl}$ concentration were the focus of the research. The concentrations of $\mathrm{TN}$, nitrate $\left(\mathrm{NO}_{3}-\mathrm{N}\right)$, dissolved $\mathrm{O}, \mathrm{Fe}$ $\left(\mathrm{Fe}^{2+} / \mathrm{Fe}^{3+}\right)$, and chloride $(\mathrm{Cl}-)$, as well as the water temperature and $\mathrm{pH}$, were measured in the $\mathrm{EC}$ reactor. By using the 3D numerical model, spatially continuous velocity fields and the TN concentration were determined. The results of this study show that the TN removal efficiency is dependent primarily on the initial concentration of $\mathrm{NaCl}$ and secondarily on the flow rate through the reactor. The initial TN concentration is reduced by $35 \%$ after 240 min of reactor operation when the flow rate is set as $0.15 \mathrm{~L} / \mathrm{s}$ and the initial $\mathrm{NaCl}$ concentration is $2 \mathrm{~g} / \mathrm{L}$, while the current density is maintained at $150 \mathrm{~A} / \mathrm{m}^{2}$. The $\mathrm{NO}_{3}-\mathrm{N}$ concentrations and $\mathrm{pH}$ are reduced by $5 \%$ with respect to the initial values.
\end{abstract}

Keywords: electrocoagulation; pilot device; numerical model; ammonia

\section{MODELIRANJE DINAMIKE UKUPNOG DUŠIKA PRI RADU ELEKTROKOAGULACIJSKOG UREĐAJA S INOKS ELEKTRODAMA}

Sažetak: Analizirana je učinkovitost elektrokoagulacijskog (EC) pilot uređaja s inoks elektrodama u postupku pročišćavanja vode opterećene povišenom koncentracijom ukupnog dušika. Dodatno je uspostavljen i 3D numerički model strujanja i pronosa. U provedbi analiza na pilot-uređaju variran je protok kroz reaktor sa inoks elektrodama te inicijalna koncentracija $\mathrm{NaCl}$. U komori EC uređaja praćene su i promjene koncentracija ukupnog dušika (TN), nitrata $\left(\mathrm{NO}_{3}-\mathrm{N}\right)$, otopljenog kisika (DO), željeza $\left(\mathrm{Fe}^{2+} / \mathrm{Fe}^{3+}\right)$ i klorida $(\mathrm{Cl})$, te promjene temperature vode i pH. Primjenom 3D numeričkog modela, definirana su polja strujanja i koncentracije ukupnog dušika u procesu pronosa. Rezultati provedenog istraživanja pokazali su da je učinkovitost procesa pročišćavanja primarno ovisna o inicijalnoj koncentraciji $\mathrm{NaCl}$, a sekundarno i o protoku kroz reaktor. Pri protoku kroz reaktor $Q$ $=0.15 \mathrm{l} / \mathrm{s}$, uz primjenu gustoće jakosti struje $150 \mathrm{~A} / \mathrm{m}^{2}$ i inicijalnu koncentraciju $\mathrm{NaCl}$ od $2 \mathrm{~g} / \mathrm{l}$, nakon 240 minuta rada elektrode postignuto je smanjenje inicijalne koncentracije $\mathrm{TN}$ od $35 \%$. Koncentracija nitrata $\left(\mathrm{NO}_{3}-\mathrm{N}\right)$ i pH smanjuju se na skali od $5 \%$ u odnosu na početne vrijednosti.

Ključne riječi: elektrokoagulacija; pilot uređaj; numerički model; amonijak

Lončar, G, Halkijević, I, Posavčić, H, Ban, I 


\section{INTRODUCTION}

Electrochemical technologies have reached a state comparable to other water treatment technologies with regard to cost and efficiency (Chen [1]). Processes such as electrooxidation, electrocoagulation (EC), and electrodisinfection are typically used. Various types of wastewaters are treated using electrochemical technologies, and extensive research has been performed on this topic by many researchers. Abuzaid et al. [2] studied nitrite removal efficiency of the electrochemical process with stainless-steel (SS) electrodes. The influences of various parameters such as the current density, volume of the solution, initial $\mathrm{pH}$, and electrode configuration, were analyzed. Furthermore, a first-order reaction model was proposed for the prediction of the nitrate removal. Vlyssides et al. [3] studied the influence of $\mathrm{pH}$ on the electrochemical treatment process with a $\mathrm{Ti} / \mathrm{Pt}$ ( $\mathrm{Ti}$ alloy with $\mathrm{Pt}$ foil) anode and an SS cathode with sodium chloride $(\mathrm{NaCl})$ as electrolyte. The authors concluded that the electrochemical treatment process is superior to conventional biological treatment, achieving almost total removal of the chemical oxygen demand (COD), suspended solids (TSS), and ammonia nitrogen. The working conditions were $15 \mathrm{~V}$ and $100 \mathrm{~A}$ with a reaction time of $120 \mathrm{~min}$. Compared with aerobic biological processes, the energy demand for the electrochemical process was ten times lower.

The electrochemical treatment of domestic wastewater without an external source of electrolyte was investigated by Bukhari et al. [4]. A $5 \mathrm{~L}$ wastewater sample was treated with $\mathrm{SS}$ electrodes having an anode area of $150 \mathrm{~cm}^{2}$ and a current of $0.4 \mathrm{~A}$. After 10 min of reaction, an efficiency of $59.4 \%$ was achieved with regard to total organic removal. Feng et al. [5] treated a domestic wastewater sample via an approach combining electrooxidation and EC processes. Separate electrooxidation $\left(\mathrm{Ti}^{2} \mathrm{RuO}_{2}-\mathrm{TiO}_{2}\right.$ anode and $\mathrm{SS}$ cathode) and $\mathrm{EC}$ (SS anode and cathode) units were used. Within the electrooxidation unit, a current density of $3 \mathrm{~mA} / \mathrm{cm}^{2}$ and a pulse voltage of $500 \mathrm{~V}$ with a frequency of $25 \mathrm{kHz}$ was applied for $15 \mathrm{~min}$. Subsequently, wastewater flowed to a sedimentation tank and then back to the EC unit. The EC-unit sample was treated for another 15 min and transferred again to the sedimentation tank for $1 \mathrm{~h}$. Approximately 90\% removal of the COD and ammonia, and $97.05 \%$ removal of TSS was achieved.

The electrooxidation process has also been successfully used to oxidize ammonia in wastewater. Lin and $\mathrm{Wu}[6]$ investigated the possibility of ammonia removal via SS electrodes. The achieved removal efficiency was only $20 \%$ after a $2 \mathrm{~h}$ test run. After switching to high-purity graphite electrodes and applying a current density of $0.44 \mathrm{~A} / \mathrm{cm}^{2}, 60 \%$ removal was achieved. The electrooxidation of ammonia in artificial seawater was investigated by Lee et al. [7]. The electrodes had an effective area of $30 \mathrm{~cm}^{2}$. The ammonia concentration exponentially decreased with the increase of the current density and treatment time. An ammonia removal efficiency of $80 \%$ was achieved after 90 min at a current density of $66 \mathrm{~A} / \mathrm{m}^{2}$.

Lin and Wu [8] studied the removal efficiency of ammonia by using electrooxidation technology with a graphite rod anode and a $\mathrm{Ti}$ cathode situated $1.5 \mathrm{~cm}$ apart. The results showed that increase of the current density has a major effect on the removal efficiency. Complete removal was observed after 10 min at a current density of $34.2 \mathrm{~mA} / \mathrm{cm}^{2}$. Kobya et al. [9] applied EC for the turbidity removal of textile wastewaters. The effects of various parameters (conductivity, $\mathrm{pH}$, current density, and operating time) on the turbidity removal efficiency were investigated. A removal efficiency of $95 \%$ was achieved by using SS electrodes, at a current density of 10 $\mathrm{mA} / \mathrm{cm}^{2}$ and an operating time of $10 \mathrm{~min}$.

Because most of the relevant research involved only small-scale laboratory reactors, the main objective of this study was to investigate the effectiveness of the combined processes of electrooxidation and EC in a fullscale reactor with SS electrodes for the removal of ammonia (from a mixture of drinking water and ammonia solution). The other objective was to create a mathematical model for the whole process so that some hydraulic effects of the constructive (design) elements of the reactor can be investigated.

\section{BASICS OF EC THEORY}

A typical electrochemical water-treatment process consists of an electrolytic cell, which comprises two electrodes: an anode and a cathode (Ghanbari et al. [10]). The electrolytic cell is immersed in an electrically conducting solution (the electrolyte), and electrodes are connected via an electrical circuit, outside the solution. The electrical circuit includes a power source with a current/voltage control device. Oxidation and reduction occur at the 
electrode/electrolyte interface. The reduction occurs at the cathode, and the oxidation occurs at the anode. The current flow through the electrodes results from the driving force of the power source that maintains the current in the electrochemical cell. The current flow is then released into the electrolyte. The electrolyte facilitates the flow by the motion of its ionic charged species and affects the formation of oxidizing species during the process. High conductivity is an additional advantage of this process as it reduces the electrical resistance of the solution. It also reduces the adverse effects of $\mathrm{HCO}_{3}{ }^{-}$and $\mathrm{SO}_{4}$. The existence of carbonate or sulfate ions leads to the precipitation of $\mathrm{Ca}^{2+}$ or $\mathrm{Mg}^{2+}$ ions, which form an insulating layer on the surface of the electrodes. This layer further disrupts the oxidation and reduction process (Chen [1]).

The EC process requires no chemical addition. The coagulants are produced in situ within the reactor by the electrolytic oxidation of the appropriate anode materials, such as SS or Al. Through this electrolytic oxidation, highly charged polymeric metal hydroxyl species are produced. The electrostatic charges on suspended solids of contamination are neutralized by these species, which also facilitate agglomeration, resulting in separation from the aqueous phase. These hydroxides remove metals, colloidal particles, and soluble organic pollutants from aqueous media. The treatment also induces the precipitation of certain metals and salts (Mollah et al. [11]).

$\mathrm{Al}$ and Fe are most commonly used as the electrodes for the EC process (Prieto-García et al. [12]). The electrodes can be in the form of plates or in the form of packed scraps, such as steel turnings or millings. Electrodes made of Fe are usually used for wastewater treatment, while $\mathrm{Al}$ is used for drinking water treatment because $\mathrm{Fe}$ is cheaper.

In this research, SS electrodes are used, as their application in ammonia removal is insufficiently investigated. When SS is used as the anode, upon oxidation in the electrolytic system, it produces iron hydroxide, i.e., $\mathrm{Fe}(\mathrm{OH})_{n}$, where $n=2$ or $n=3$. Two mechanisms have been proposed to produce $\mathrm{Fe}(\mathrm{OH})_{n}$, and the second one is used in this study.

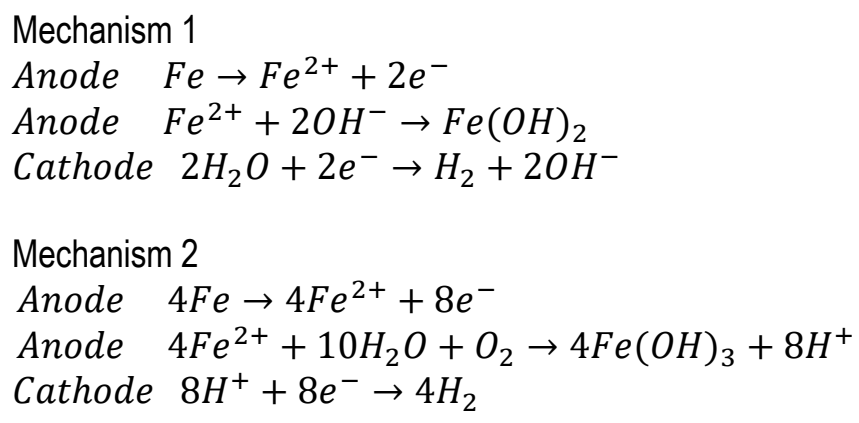

$$
\begin{aligned}
& \text { Mechanism } 2 \\
& \text { Anode } 4 \mathrm{Fe} \rightarrow 4 \mathrm{Fe}^{2+}+8 e^{-} \\
& \text {Anode } 4 \mathrm{Fe}^{2+}+10 \mathrm{H}_{2} \mathrm{O}+\mathrm{O}_{2} \rightarrow 4 \mathrm{Fe}(\mathrm{OH})_{3}+8 \mathrm{H}^{+} \\
& \text {Cathode } 8 \mathrm{H}^{+}+8 e^{-} \rightarrow 4 \mathrm{H}_{2}
\end{aligned}
$$

In addition to the above hydroxyl species, electrogenerated ferric ions form monomeric ferric hydroxo complexes with hydroxide ions and polymeric species, which are transformed into $\mathrm{Fe}(\mathrm{OH})_{3}$ (depending on the $\mathrm{pH}$ range, usually at a pH around 8) (Kobya et al. [9], Benefield et al. [13]). In the presence of hypochlorous acid, it is considered that ammonia oxidation involves the following complex reaction sequence (Krstajic and Nakic [14]).

$$
\begin{aligned}
& \mathrm{NH}_{4}+\mathrm{HOCl} \rightarrow \mathrm{NH}_{2} \mathrm{Cl}+\mathrm{H}_{2} \mathrm{O}+\mathrm{H}^{+} \\
& \mathrm{NH}_{2} \mathrm{Cl}+\mathrm{HOCl} \rightarrow \mathrm{NHCl}_{2}+\mathrm{H}_{2} \mathrm{O} \\
& \mathrm{NH}_{2} \mathrm{Cl}+\mathrm{H}_{2} \mathrm{O} \rightarrow \mathrm{NOH}+2 \mathrm{H}^{+}+2 \mathrm{Cl}^{-} \\
& \mathrm{NHCl}_{2}+\mathrm{NOH} \rightarrow \mathrm{N}_{2}+\mathrm{HOCl}+\mathrm{H}^{+}+\mathrm{Cl}^{-}
\end{aligned}
$$

\section{MATERIALS AND METHODS}

A pilot EC device was constructed in the hydrotechnical laboratory at the Faculty of Civil Engineering, University of Zagreb. A schematic view of the device is shown in Figure 1. The geometry of the reactor, including the sink (intake) and source positions, is identical between the physical and numerical models. For the numerical model, the intake (sink) position of the pipe connecting the chamber with the SS electrodes and the pipe outlet (source) position in the chamber are defined by the performance of the physical model (Figure 1) and remain unaltered during the course of the study. 
(a)

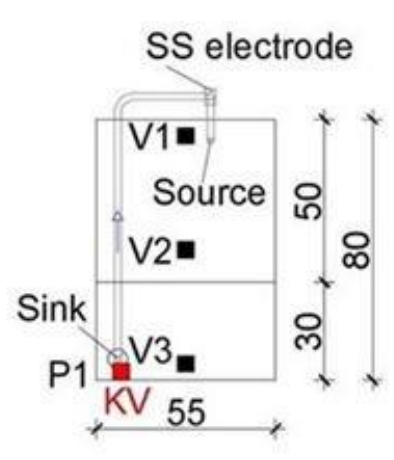

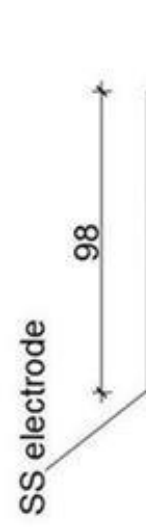

(b)

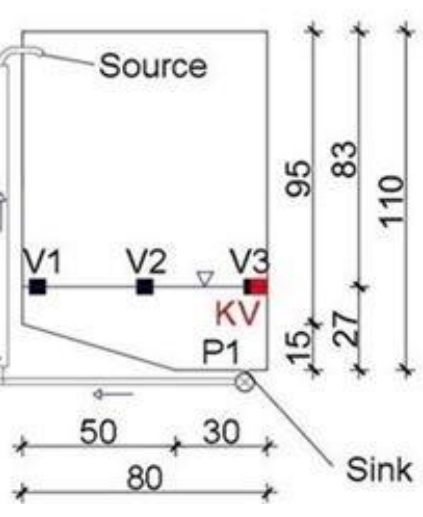

(c)

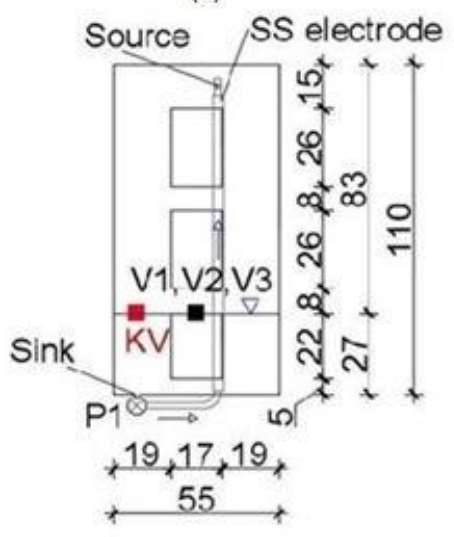

(d)

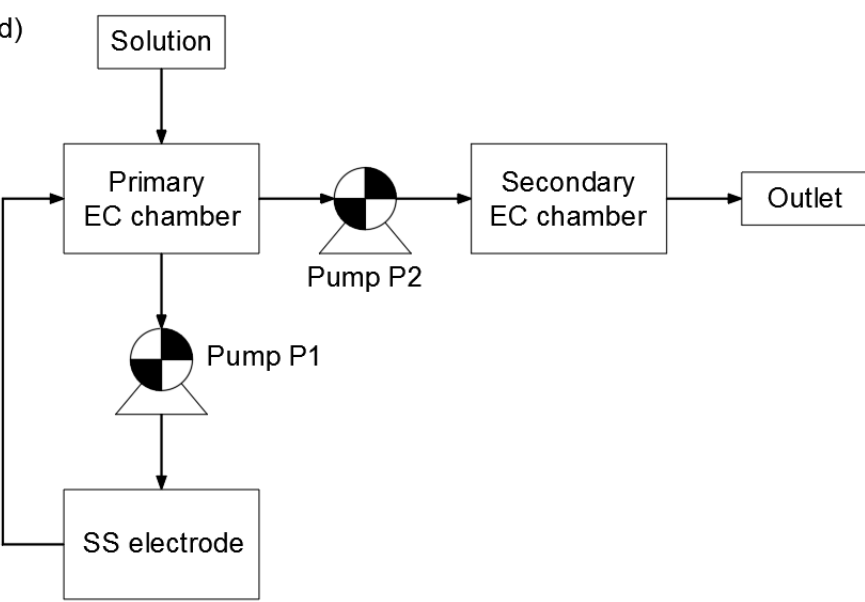

Figure $1 \mathrm{EC}$ device with a schematic representation and technological scheme (Figure 1d), indicating the velocity measurement positions (V1-V3) at a depth of $3 \mathrm{~cm}$ and the water sampling position for measuring the water-quality parameters of the surface layer (KV) (Figs. 1a-1c)

The whole water-treatment process is divided into several phases. The primary chamber is filled with water from the Zagreb City public water supply system to a depth of $h=0.275 \mathrm{~m}$ (90 L, Figure 1). After adding $70 \mathrm{~mL}$ of a $25 \% \mathrm{NH}_{3}$ solution and stirring until a homogeneous initial TN concentration of $200 \mathrm{mg} / \mathrm{L}$ is reached, an appropriate amount of $\mathrm{NaCl}$ is added to achieve homogeneous initial concentrations of 0.2 or $2 \mathrm{~g} / \mathrm{L}$. Subsequently, pump P1 (Figure 1) is activated to transport water from the bottom of the reactor through the SS sacrificial electrodes. After the passage through the electrodes with a flow rate of 0.05 or $0.15 \mathrm{~L} / \mathrm{s}$, the water returns to the chamber in the form of a free-falling jet, impinging the water surface at the position shown in Figure 1. The total reaction time is $240 \mathrm{~min}$. After the $240 \mathrm{~min}$, the water is left to rest for another $60 \mathrm{~min}$ (precipitation period). Then, the water is pumped to the secondary chamber using pump P2. The initial assumptions are adopted to compare the obtained results with previous research, for representing realistic operating conditions and the measuring range of the available equipment.

Water samples for concentration measurements are taken at the KV position (Figure 1), prior to the activation of the reactor (initial state) and every $60 \mathrm{~min}$. Measurements were taken for the concentrations of total $\mathrm{N}(\mathrm{TN})$, nitrate $\left(\mathrm{NO}_{3}-\mathrm{N}\right)$, dissolved $\mathrm{O}(\mathrm{DO})$, $\mathrm{Fe}\left(\mathrm{Fe}^{2+} / \mathrm{Fe}^{3+}\right)$, and chloride $(\mathrm{Cl})$, as well as for the water temperature and $\mathrm{pH}$ changes. The velocity was measured at three points 
(coordinates shown in Figure 1), at a depth of $3 \mathrm{~cm}$. The recording period was set to $1 \mathrm{~min}$ for each measurement point.

For the $\mathrm{TN}$ and $\mathrm{NO}_{3}-\mathrm{N}$ concentrations, a digital photometer (NANOCOLOR 500D, Eutech) with a photometric accuracy of $\pm 1 \%$ was used. Method 0881 (Test 0-88, ref 985 088) and method 0641 (Test 0-64, ref 985 064) were applied for the $\mathrm{TN}$ and $\mathrm{NO}_{3}-\mathrm{N}$ measurements, respectively. The $\mathrm{Fe}$ concentrations $\left(\mathrm{Fe}^{2+} / \mathrm{Fe}^{3+}\right)$ were measured using a digital photometer via method 0371 (Test 0-37, ref 985 037). The chloride $(\mathrm{Cl})$ concentrations were measured with respect to the initial salt concentration. When the initial concentration was $2.0 \mathrm{~g} / \mathrm{L}$, the $\mathrm{Cl}$ - concentration was estimated using Quantofix Chloride test strips (Macherey-Nagel) with gradations between 500 and $3,000 \mathrm{mg} / \mathrm{L} \mathrm{Cl}$. In the case where the initial salt concentration was $0.2 \mathrm{~g} / \mathrm{L}$, a digital photometer (NANOCOLOR 500D) was used, and method 0191 (Test 0-19, ref 985 019) was applied. The flow was measured using an ultrasonic meter (FLUXUS F601, Flexim). The water temperature, $\mathrm{pH}$ (resolution: 0.001; accuracy: \pm 0.002 ), and DO concentration (resolution: $0.01 \mathrm{mg} / \mathrm{L}$; accuracy: $\pm 0.2 \mathrm{mg} / \mathrm{L}$ ) were measured using Multiprobe CyberScan PCD 650 (Eutech). The velocities were measured using a three-dimensional (3D) acoustic meter (Vectrino, Nortek; diameter of the sampling volume: $6 \mathrm{~mm}$; velocity range: \pm 0.03 to $\pm 4 \mathrm{~m} / \mathrm{s}$; accuracy: $\pm 0.5 \%$ ).

Numerical simulations were performed using the 3D numerical model Mike $3(\mathrm{DHI})$. This model is based on the finite differential method, with the " $\mathrm{z}$ " coordinate system in the vertical direction and structured spatial discretization. Horizontally, the spatial domain (Figure 2) is discretized by an equidistant step: $\Delta x=\Delta y=\Delta z=0.025 \mathrm{~m}(22 \times 32 \times 11$ cells $)$.

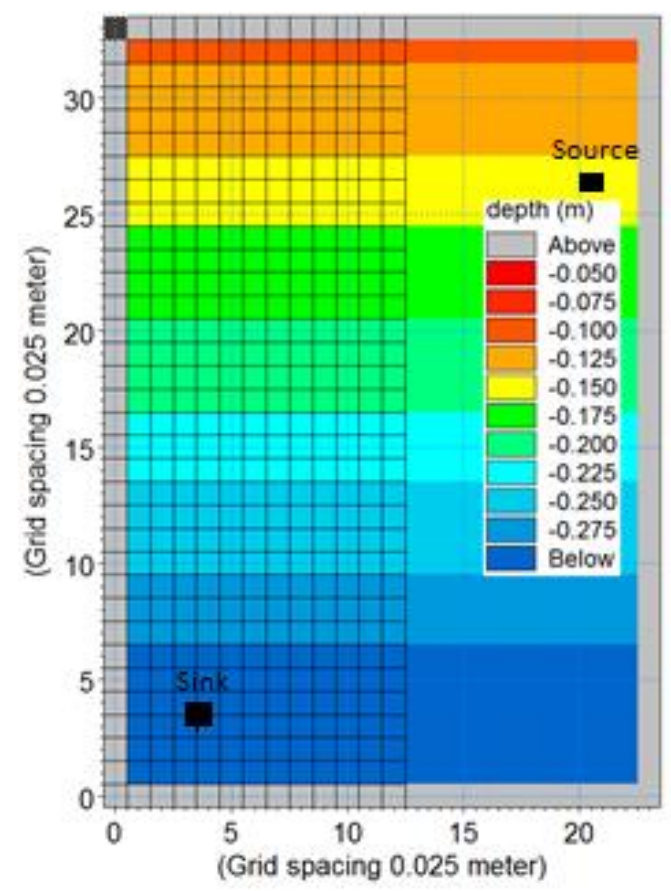

Figure 2 Spatial discretization of the model domain (structured calculation mesh)

The mathematical foundation of Mike 3 comprises the mass-conservation equation; the Reynolds-averaged Navier-Stokes equations, including the effect of the turbulence and variable density; and the conservation equations for scalar fields such as salinity and temperature. The model-governing equations are explained in detail in a previous paper (Lončar et al. [15]).

The turbulent closure model used within Mike 3 relies on a $k-\varepsilon$ formulation in the vertical direction (Ferziger [16], Rodi [17]) and the Smagorinsky concept in the horizontal direction (Smagorinsky [18]).

The model employs the artificial compressibility method (Chorin [19], Ferziger [16], Rasmussen [20], Casulli [21]) and the alternating direction implicit technique to integrate the equations for mass and momentum Lončar, G, Halkijević, I, Posavčić, H, Ban, I 
conservation in the space-time domain (Abbot and Basco [22]). The equation matrices were resolved by a double-sweep algorithm and discretized on an Arakawa C-grid with second-order accuracy (Richtmeyer and Morton [23]). The 3D Quickest-Sharp scheme was used for the analysis of the transported scalar fields (Vested et al. [24], Gross et al. [25]).

The transport model was implemented via an appropriate mathematical formulation that interprets the dynamics of dissolved or suspended substances through the interaction links with certain variables in the process. The process equations give a mathematical description of the process-variable transformation for the purpose of determining its condition. The process variables are mutually coupled to the source/sink member. The defined coupled set of ordinary differential equations is solved by integrating the rate of change of the concentration for a particular process variable and the advective-dispersive process.

A model of the TN dynamics for water treatment via the EC process with SS electrodes is presented below. This model includes the creation and settling of flocs, as well as the processes of adsorption and desorption of the flocs. The transport mechanism and chemical transformations of ammonia and nitrate are not primarily related to the adsorption and desorption processes. The results of the research conducted by Emamjomeh and Sivakumar [26] indicate the absence of $\mathrm{N}$ compounds in the precipitated floc layers in the EC process with $\mathrm{Al}$ electrodes. In addition, Emamjomeh and Sivakumar [27] have argued the emergence of anionic nitrate electroreduction on the cathode and its transfer to nitrite, ammonia, and gaseous nitrogen. However, to the knowledge of the authors, the absence of $\mathrm{N}$ compounds in flocculants generated by Fe or SS electrodes has not been published thus far. It is also known that, for example, phosphate is removed through complexation and precipitation with metal hydroxides and/or adsorption on them (Hakizimana et al. [28]). Therefore, the model presented in this study is suitable for recognizing the presence or absence of $\mathrm{N}$-compound adsorption and for accepting/rejecting the proposed formulation of the TN removal process with SS electrodes.

The numerical simulations show changes in the concentration fields of the dissolved and suspended fractions of the analyzed substance through the water column. It is assumed that the organic fraction in TN is negligible and that the TN concentration in water is divided into two fractions: dissolved $\left(T N_{D}\right)$ and adsorbed onto flocculated particles $\left(T N_{S}\right)$. Therefore, three process variables are defined: the concentration of dissolved $\left(T N_{D}\right)$ and adsorbed $\left(T N_{S}\right)$ fractions in the water column and the concentration of suspended particles (flocs) in the column of water, $\gamma$ s. For each process variable, corresponding differential equations describing the rate of change are proposed. These equations also include process constants and auxiliary variables.

The equation for the TN concentration dissolved in the water column $T N_{D}$ is as follows.

$d\left(T N_{D}\right) / d t=k_{d}\left(T N_{S}\right)-k_{d} K_{D}\left(T N_{D}\right) \gamma_{S}$

$k_{d} K_{D}=K_{a}$

Here, $k_{d}$ and $k_{a}$ are the coefficients of desorption and adsorption, respectively, of TN on flocs; $K_{a}$ is the adsorptive velocity coefficient; and $K_{D}$ is partition coefficient for TN between the dissolved and adsorbed fractions.

Eq. 3 defines the $T N_{S}$ concentration adsorbed as flocs. Eq. 4 describes the sedimentation process participation:

$$
\begin{aligned}
& d\left(T N_{S}\right) / d t=-k_{d}\left(T N_{S}\right)+k_{d} K_{D}\left(T N_{D}\right) \gamma_{S}-\operatorname{sed}\left(T N_{S}\right) \\
& \operatorname{sed}\left(T N_{S}\right)=w_{S}\left(T N_{S} / d z\right)
\end{aligned}
$$

Here, $w_{s}$ is the floc settling velocity, and $d z$ is the cell thickness.

The change in the mass concentration of flocs $d \gamma_{s} / d t$ is expressed by Eq. 5 . The member for counting the sedimentation process is also included (Eq. 6).

$$
\begin{aligned}
& d \gamma_{S} / d t=-\operatorname{sed}\left(T N_{S}\right)+S \gamma_{S} \\
& \operatorname{sed}\left(\gamma_{S}\right)=w_{S}\left(\gamma_{S} / d z\right)
\end{aligned}
$$

Here, $S \gamma_{S}$ is the local source/sink of suspended particles (flocs) in the water column.

To adopt a rational value for $S \gamma_{S}$ (Eq. 5) in the numerical simulations, several steps are performed. First, the amount of metal dissolved by anodic oxidation is calculated according to Faraday's law (Eq. 7).

$$
m=(\phi \mid t M) /(Z F)
$$


Here, $m$ is the mass of metal in grams, $t$ is the electrode time $(4 \mathrm{~h}), I$ is the current strength $(10 \mathrm{~A}), M$ is the molecular weight of SS $(55 \mathrm{~g} / \mathrm{mol}), z=2$ is the number of electrons transferred, $F$ is the Faraday constant $(96,487$ $\mathrm{C} / \mathrm{mol})$, and $\phi=1$ is the correction coefficient.

Under an alkaline condition, $\phi<1$ (Sasson [29]). Using the adopted values, $m=41 \mathrm{~g}$ of SS for $4 \mathrm{~h}$ of SSelectrode operation. Accordingly, the intensity of the source is adopted with the value $S \gamma_{s}=58 \mathrm{mg} / \mathrm{Ls}$ (for the reactor flow rate of $0.05 \mathrm{~L} / \mathrm{s})$.

The exponential formulation proposed by Lai and Lin [30] (Eq. 8) is used for $w_{s}$, as indicated by Eqs. 4 and 6.

$$
w_{s}=k_{w} \exp \left(-n / \gamma_{S}\right)
$$

Here, $k_{w}$ and $n$ are parameters (constants) of the floc settling-velocity model.

To determine the optimal values of the model constants $K_{D}, k_{d}, k_{w}$, and $n$ (model parameterization), the results of the measurement of the EC device were used. Preliminary numerical simulations were performed to identify the appropriate range (Table 1) of values for the constants in the TN transport model, considering the actual geometrical characteristics of the EC device and the working conditions (flow rate and operation time).

\section{MODELING AND MEASUREMENT RESULTS}

Figure 3 compares the average measured and modeled flow velocities for three measurement positions. The average measured flow velocities, although very small, are higher than the modeled ones. Their general layout, regarding the measurement positions, is similar. Figure 4 shows the modeled horizontal velocity field for the surface, intermediate, and bottom layers during the operation of the SS reactor with a flow rate of $0.15 \mathrm{~L} / \mathrm{s}$. The velocity increases near the source and sink, as expected.

Three experiments were performed using the pilot device (Table 2). The measured values of the monitored water-quality parameters were used for obtaining appropriate values of the constants in the kinetic models (parameterization of numerical transport model).
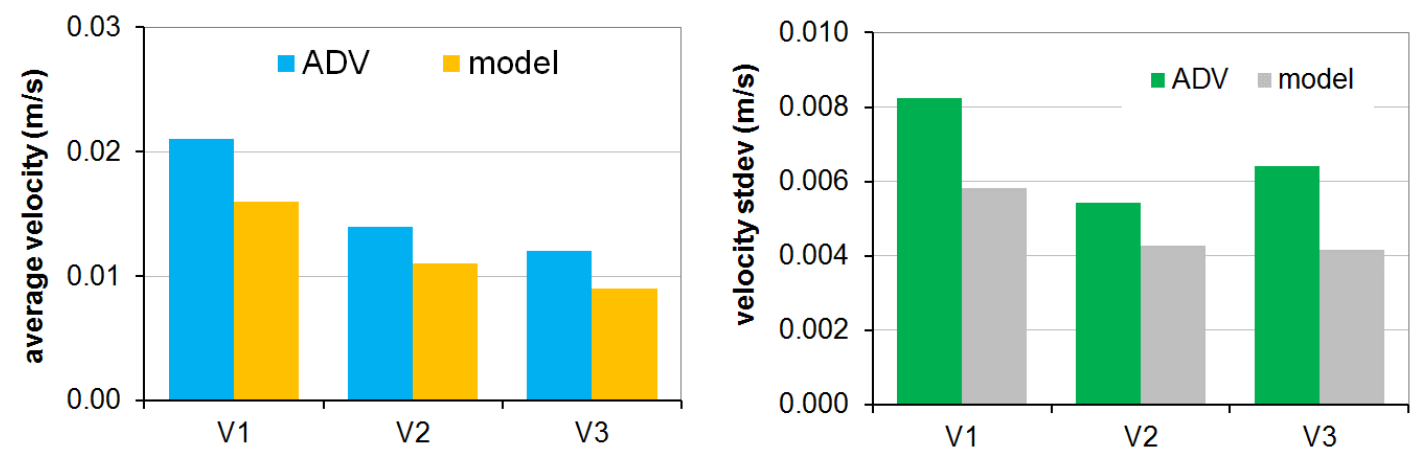

Figure 3 Comparison of average measured and modeled flow velocities and corresponding standard deviations for four flow-velocity measurement positions (1-min averaging period) 


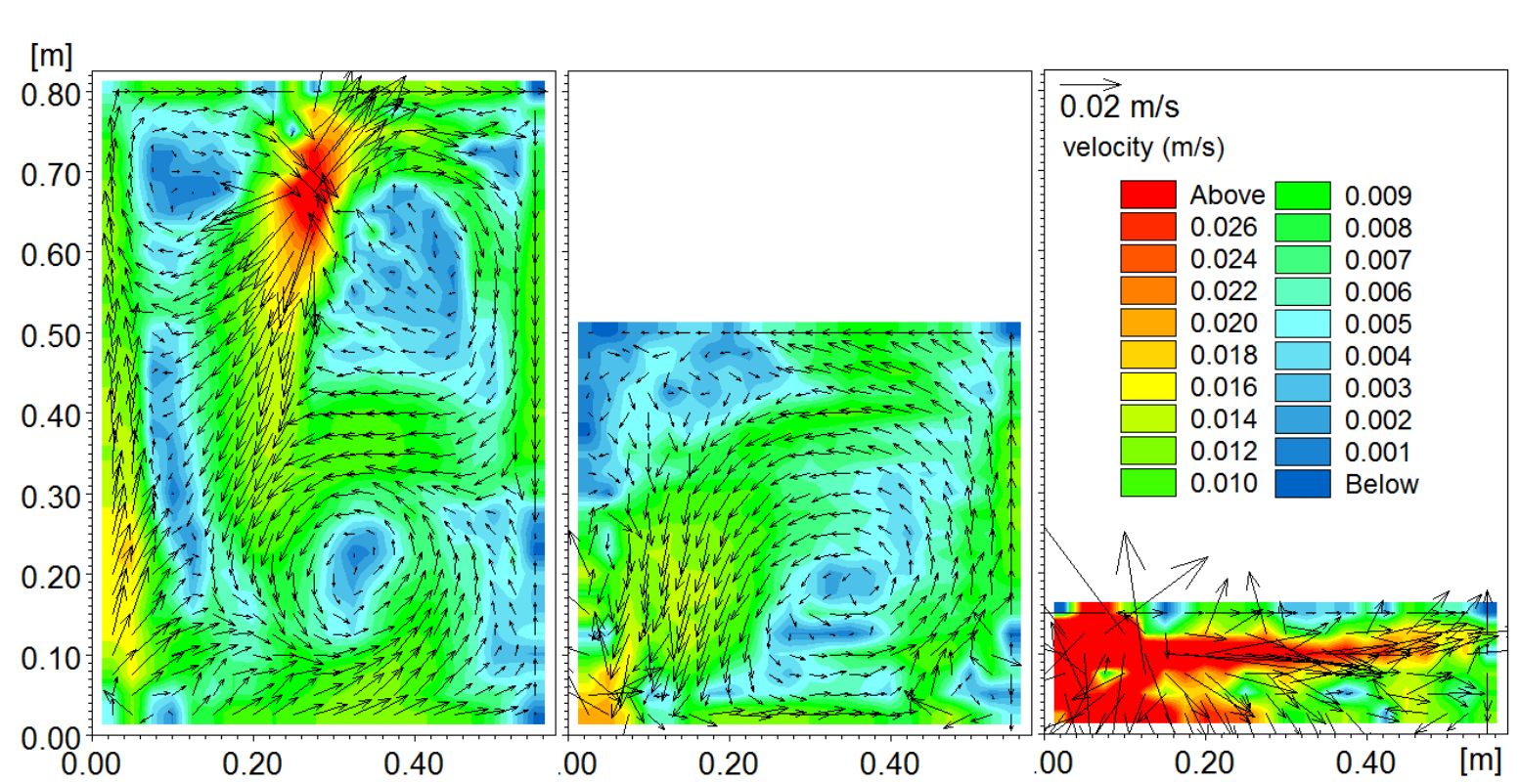

Figure 4 Model horizontal velocity field for the surface $(-1 \mathrm{~cm}$, left), intermediate $(-13 \mathrm{~cm}$, middle), and bottom $(-27 \mathrm{~cm}$, right) layers during the operation of the $S S$ reactor with a flow rate $0.15 \mathrm{~L} / \mathrm{s}$

Table 1 Nomenclature of experiments on physical model with results of initial concentration decrease: $\mathrm{TN}_{\mathrm{D} 0}=200 \mathrm{mg} / \mathrm{L}$ after $240 \mathrm{~min}$ of reactor activity $\left(Q-\right.$ flow through reactor, $S_{\mathrm{NaCl}}$ - initial $\mathrm{NaCl}$ concentration in chamber)

\begin{tabular}{|c|c|c|c|c|}
\hline Experiment & $Q$ & $\begin{array}{c}K_{D \min } / K_{D \max } \\
\Delta K_{D}\end{array}$ & $\begin{array}{c}k_{W \min } / k_{W \max } \\
\Delta k_{W}\end{array}$ & $\begin{array}{c}n_{\min } / n_{\max } \\
\Delta n\end{array}$ \\
\hline & (L/s) & $\left(\mathrm{m}^{3} / \mathrm{kg}\right)$ & (1) & (1) \\
\hline 1 & 0.05 & $\begin{array}{c}100 / 250 \\
25\end{array}$ & $\begin{array}{c}10 / 250 \\
10\end{array}$ & $\begin{array}{c}0.01 / 0.09 \\
0.005\end{array}$ \\
\hline 2 & 0.15 & $\begin{array}{c}100 / 250 \\
25\end{array}$ & $\begin{array}{c}10 / 40 \\
1\end{array}$ & $\begin{array}{c}0.01 / 0.09 \\
0.005\end{array}$ \\
\hline 3 & 0.05 & $\begin{array}{c}100 / 250 \\
25\end{array}$ & $\begin{array}{c}1 / 40 \\
1\end{array}$ & $\begin{array}{c}0.01 / 0.09 \\
0.005\end{array}$ \\
\hline SS $O P T$ & - & 175 & 20 & 0.025 \\
\hline
\end{tabular}

Figure 5 shows the measured and the modeled time series of the $T N_{D}$ concentrations at the measurement position $\mathrm{KV}(\mathrm{X}=8 \mathrm{~cm}, \mathrm{Y}=0 \mathrm{~cm}, \mathrm{Z}=-3.5 \mathrm{~cm} \rightarrow 3.5 \mathrm{~cm}$ below water surface) for experiments 1, 2, and 3 (Table 2). The analyzed ranges of the model constants $K_{D}, k_{w}$, and $n$ used in the numerical model are shown in Table 1. The optimum values, SS $S_{\mathrm{OPT}}$, are obtained according to the best match of the $T N_{D}$ concentrations measured during the operating time (240 $\mathrm{min})$.

Table 2 Range of model constants $\left(K_{D}, k_{w}, n\right)$ together with intervals $(\Delta)$ of change in analyzed range and determined optimum values (SS $S_{O P T}$ )

\begin{tabular}{cccc}
\cline { 2 - 4 } Experiment & $\mathbf{Q}$ & $\mathrm{S}_{\mathrm{NaCl}}$ & $\mathrm{TN}$ removal $(\%)$ \\
\cline { 2 - 4 } & $(\mathrm{L} / \mathrm{s})$ & $(\mathrm{g} / \mathrm{L})$ & $\left(\mathrm{C}_{0} \rightarrow \mathrm{C}_{240 \mathrm{~min}} ; \Delta \mathrm{C}_{240 \mathrm{~min}}\right)$ \\
\hline 1 & 0.05 & 2 & $31(200 \rightarrow 138 ; 62 \mathrm{mg} / \mathrm{L})$ \\
2 & 0.15 & 2 & $35(200 \rightarrow 131 ; 69 \mathrm{mg} / \mathrm{L})$ \\
3 & 0.05 & 0.2 & $20(200 \rightarrow 157 ; 41 \mathrm{mg} / \mathrm{L})$ \\
\hline
\end{tabular}


The results of the numerical simulations (Figure 5) were obtained by adopting the following values of the constants and transport-model parameters: $k_{d}=1 \mathrm{~d}^{-1}$; partition coefficient for TN between dissolved and adsorbed fractions, $K_{D}=175 \mathrm{~m} 3 / \mathrm{kg}$; parameters (constants) of floc settling-velocity model according to Eq. $8-n=0.025$ and $k_{w}=20$.

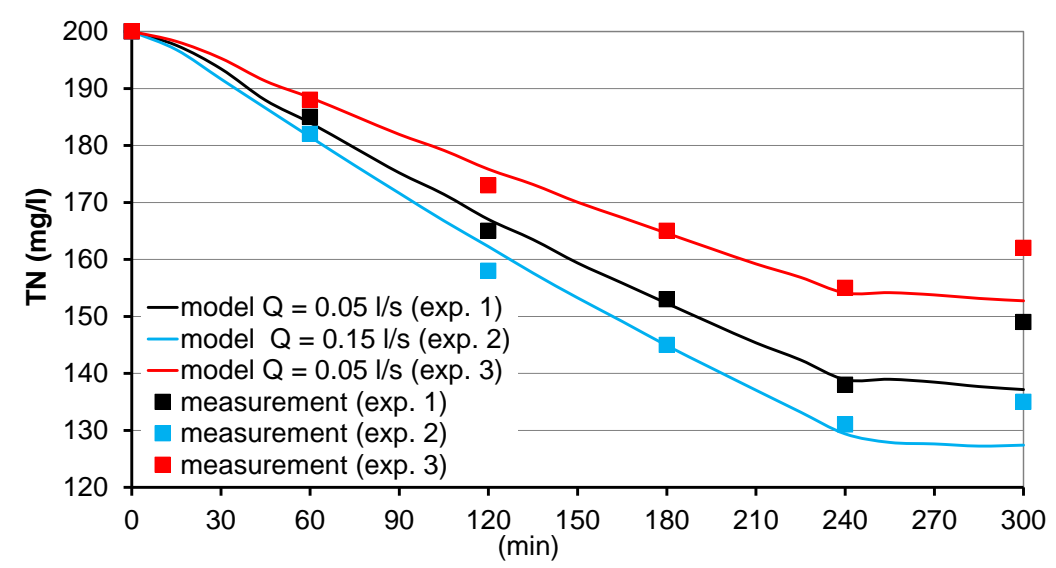

Figure 5 Measured and modeled time series of $T N_{D}$ concentrations at the position $K V(X=8 \mathrm{~cm}, Y=0 \mathrm{~cm}$, $Z=-3.5 \mathrm{~cm} \rightarrow 3.5 \mathrm{~cm}$ below water surface) for experiments 1,2 , and 3

Figure 5 clearly shows that the highest efficiency of TN removal is achieved by using the initial concentration of $2 \mathrm{~g} / \mathrm{L} \mathrm{NaCl}$ and a flow rate of $Q=0.15 \mathrm{~L} / \mathrm{s}$ through the reactor (experiment 1, Table 2). Interestingly, the TN concentration increases after $60 \mathrm{~min}$ of precipitation, which is not well-reproduced by the numerical model simulations. It can also be argued that the increase of the TN concentration during the last $60 \mathrm{~min}$ of the process is more pronounced in case of a flow rate of $Q=0.05 \mathrm{~L} / \mathrm{s}$ (experiments 1 and 3). This indicates more intensive mixing at a flow rate of $Q=0.15 \mathrm{~L} / \mathrm{s}$ and consequently a more homogeneous TN concentration field in the vertical and horizontal directions. This finding is confirmed by the results of the numerical simulations, as shown below.

Figure 6 shows the measured concentrations of $\mathrm{NO}_{3}-\mathrm{N}, \mathrm{Fe}^{2+} / \mathrm{Fe}^{3+}, \mathrm{DO}$, and $\mathrm{Cl}$, along with the $\mathrm{pH}$ and water temperature, at the position $\mathrm{KV}(X=8 \mathrm{~cm}, Y=0 \mathrm{~cm}, Z=-3.5 \mathrm{~cm} \rightarrow 3.5 \mathrm{~cm}$ below water surface) in experiments 1 and 2 (Table 2). The values are obtained in the initial state $(0 \mathrm{~min})$ and every $60 \mathrm{~min}$.

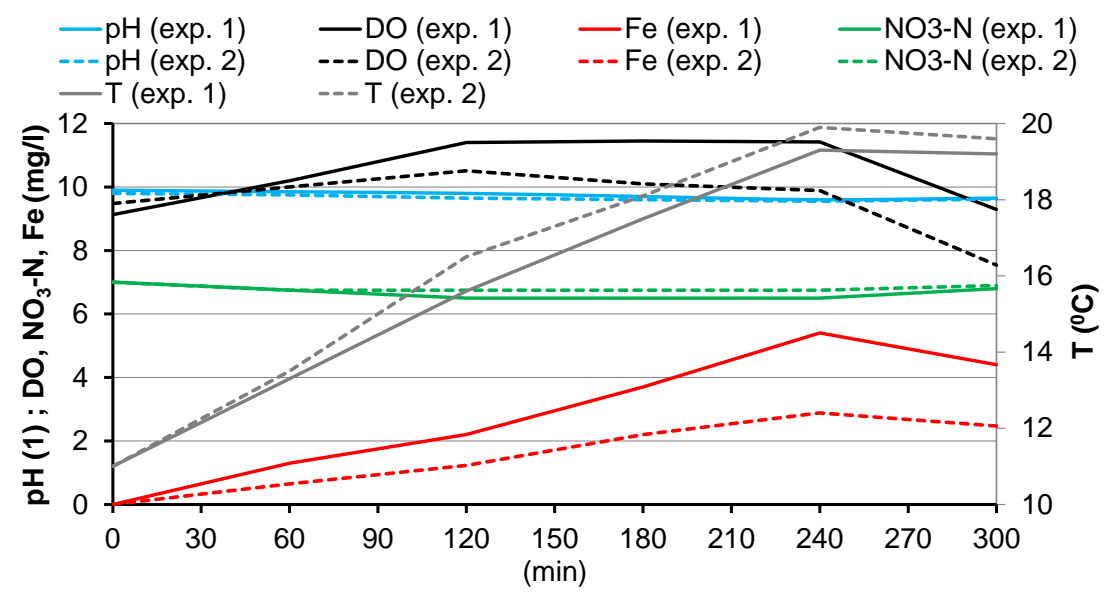

Figure 6 Measured values of $\mathrm{NO}_{3}-\mathrm{N}, \mathrm{Fe}^{2+} / \mathrm{Fe}^{3+}, \mathrm{DO}$, and $\mathrm{Cl}$ concentrations, as well as the water temperature and $\mathrm{pH}$, at the position $\mathrm{KV}(\mathrm{X}=8 \mathrm{~cm}, Y=0 \mathrm{~cm}, \mathrm{Z}=-3.5 \mathrm{~cm} \rightarrow 3.5 \mathrm{~cm}$ below the water surface) in experiments 1 and 2

Figure 6 illustrates the linear increase in the Fe concentration and temperature during the electrode operation and their decline during the precipitation period. The measured Fe concentration gain is approximately doubled for a flow rate of $Q=0.05 \mathrm{~L} / \mathrm{s}$. Because the oxidation of the anode and the generation of flocs in the 
reactor depend not on the flow through the reactor but primarily on the applied current (see Eq. 7), it can be concluded that this result is the consequence of a lower Fe concentration in the water coming out of the reactor with a flow rate $Q=0.15 \mathrm{~L} / \mathrm{s}$, as well as the more intensive mixing in the chamber at a flow rate of $Q=0.15 \mathrm{~L} / \mathrm{s}$ compared with $Q=0.05 \mathrm{~L} / \mathrm{s}$. Furthermore, a slight $\mathrm{pH}$ drop occurs during the process, which is in accordance with the results and interpretation reported by Chen [1].It is interesting to note the increase of the DO concentration during the SS-electrode operation. After detailed literature survey, no articles concerning the DO dynamics in the scope of EC processes were found. The registered occurrence of the DO concentration increase is most likely due to the reduction of $\mathrm{Cr}^{6+}$ (formed by oxidation of SS electrode) with $\mathrm{Fe}^{2+}$. Given that this reduces the $\mathrm{Fe}^{2+}$ concentration, the amount of $\mathrm{DO}$ required for its oxidation to $\mathrm{Fe}^{3+}$ decreases. Therefore, the $\mathrm{O}_{2}$ generated on the anode appears to be sufficient for increasing the DO. The results of Buerge and Hug [31] support this claim. In that study, the reduction rate of $\mathrm{Cr}^{6+}$ with $\mathrm{Fe}^{2+}$ was compared with the oxidation rate of $\mathrm{Fe}^{2+}$ with $\mathrm{DO}$. It was found that the reduction of $\mathrm{Cr}^{6+}$ with $\mathrm{Fe}^{2+}$ occurs $10^{3}$ times faster than the oxidation of $\mathrm{Fe}^{2+}$ with $\mathrm{DO}$ at a pH of 8 . $\mathrm{He}$ et al. [32] showed that $\mathrm{Fe}^{2+}$ is an effective reducing agent for $\mathrm{Cr}^{6+}$ even in hyper alkaline conditions, assuming intensive mixing.

Figure 7 shows the modeled horizontal TND concentration fields after $240 \mathrm{~min}$ of SS-electrode operation with flow rates of 0.05 and $0.15 \mathrm{~L} / \mathrm{s}$.

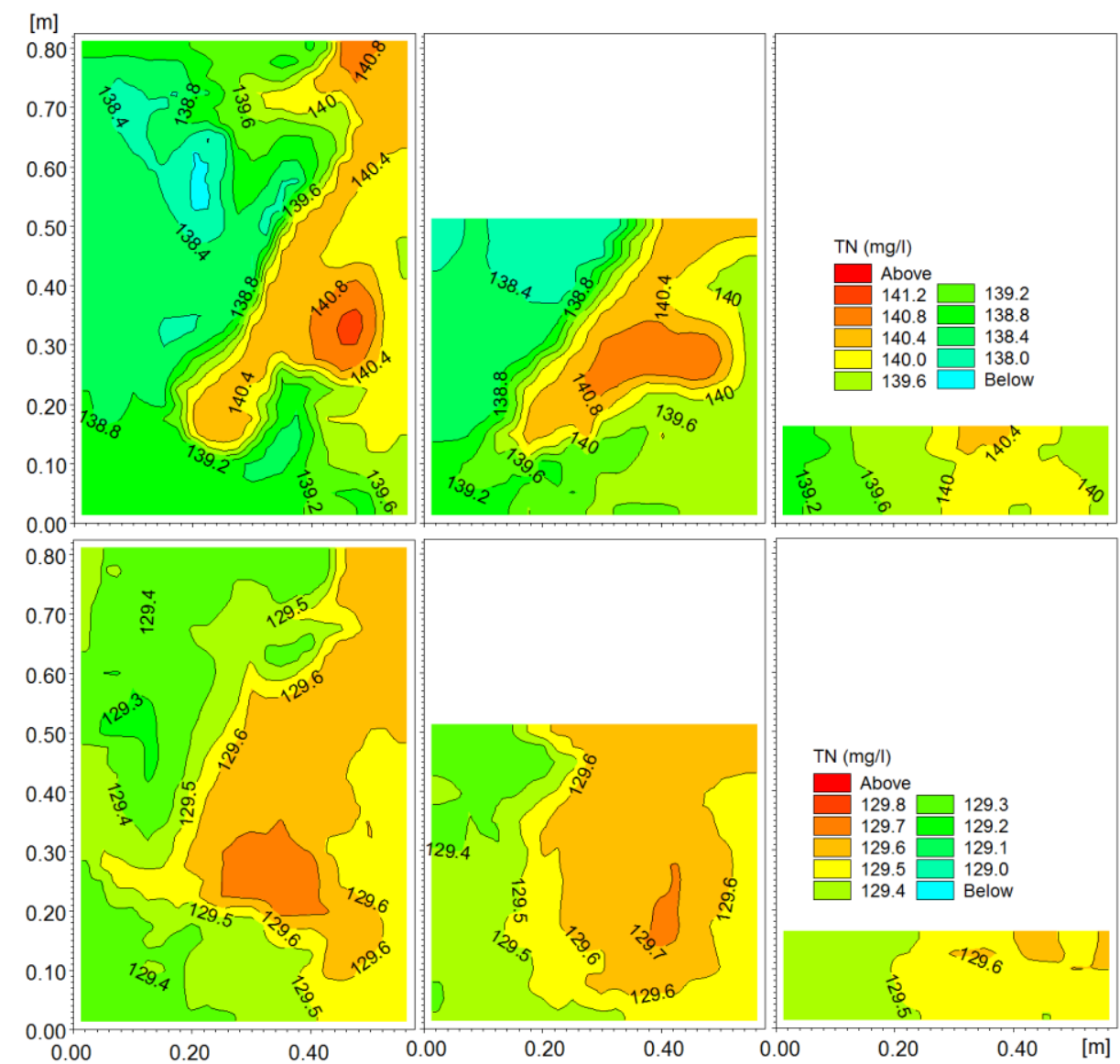

Figure 7 Modeled horizontal $T N_{D}$ concentration fields in surface $(-1 \mathrm{~cm}$, left), intermediate $(-13 \mathrm{~cm}$, middle), and bottom $(-27 \mathrm{~cm}$, right) layers after $240 \mathrm{~min}$ of SS-electrode operation (above, flow rate of 0.05 $\mathrm{L} / \mathrm{s}$; below, $0.15 \mathrm{~L} / \mathrm{s}$ )

Figure 7 indicates approximately homogeneous $T N_{D}$ concentrations in the horizontal and vertical directions under the conditions of experiment $2(Q=0.15 \mathrm{~L} / \mathrm{s})$. In contrast, the calculated $T N_{D}$ field under the conditions of experiment $1(Q=0.05 \mathrm{~L} / \mathrm{s})$ exhibits stronger pronounced variation, primarily because of the weaker water mixing. Under the conditions of experiment $1(Q=0.05 \mathrm{~L} / \mathrm{s})$, the $T N_{D}$ concentration in the surface layer varies from 137.9 $\mathrm{mg} / \mathrm{L}$ to the maximum value of $141.3 \mathrm{mg} / \mathrm{L}$, and that in the bottom layer varies from 138.8 to $140.7 \mathrm{mg} / \mathrm{L}$. On the Lončar, G, Halkijević, I, Posavčić, H, Ban, I 
other hand, under the conditions of experiment $2(Q=0.15 \mathrm{~L} / \mathrm{s})$, the concentration of $T N_{D}$ varies within a narrower range, between the minimum value of $129.2 \mathrm{mg} / \mathrm{L}$ and the maximum value of $129.8 \mathrm{mg} / \mathrm{L}$. The same surfacelayer results shown in Figure 7, with respect to the sampling position, are observed in Figure 5.

During the reactor operation, a linear increase in the Fe concentration and water temperature was observed, together with a linear decrease in the $\mathrm{pH}$. The Fe concentration approximately doubles if the reactor flow rate is set as $Q=0.05 \mathrm{~L} / \mathrm{s}$, compared with the flow rate of $Q=0.15 \mathrm{~L} / \mathrm{s}$. At the flow rate of $Q=0.05 \mathrm{~L} / \mathrm{s}$, the DO concentration linearly increases during the first $120 \mathrm{~min}$ of the reactor operation and then retains the achieved value until the reactor is turned off. At the flow rate of $Q=0.15 \mathrm{~L} / \mathrm{s}$, there is also a linear increase in the concentration of DO in the first 120 min of the process, after which a linear decrease occurs during the remaining $120 \mathrm{~min}$ of the process (from 120 to $240 \mathrm{~min}$ ). The DO-concentration increase is most likely the consequence of $\mathrm{Cr}^{6+}$ reduction with $\mathrm{Fe}^{2+}$, followed by reduced $\mathrm{DO}$ consumption in $\mathrm{Fe}^{2+}$ oxidation to $\mathrm{Fe}^{3+}$.

\section{CONCLUSIONS}

The efficiency of the EC process, observed through the reduction of the TN concentration, is primarily dependent on the initial $\mathrm{NaCl}$ concentration. The flow rate through the reactor is a less influential parameter. After a process duration of $240 \mathrm{~min}$, using an initial $\mathrm{NaCl}$ concentration of $2 \mathrm{~g} / \mathrm{L}$, a current density of $150 \mathrm{~A} / \mathrm{m}^{2}$ on the SS electrodes, and a flow rate $Q$ of $0.15 \mathrm{~L} / \mathrm{s}$ through the reactor, the TN concentration was reduced by $35 \%$.

It can be concluded that TN reduction using the reactive SS electrodes is not as effective as that using nonreactive electrodes (graphite, $\mathrm{Pt}, \mathrm{Ti}$, etc.), which can oxidize the compounds that undergo highly complex reactions. Thus, if only SS electrodes are used, a limited TN reduction efficiency can be expected. It is shown that a full-scale reactor with SS electrodes achieves the same level of efficiency as a small-scale unit and can operate within realistic values of the process parameters, indicating potential for practical application in wastewater treatment. However, in situations where high ammonia concentrations are expected, the combined use of SS and non-reactive electrodes is required.

A unique methodological approach for EC process modeling was presented in Chapter 3 . The developed mathematical model shows satisfying results with regard to the adsorption and precipitation processes but does not cover the increase of the TN concentration after the precipitation period, as shown in Figure 5 . The reason for this may be the desorption occurring with the increased concentration of settled flocs. Thus, in the next phases of the model development, it is necessary to devote greater attention to the desorption coefficient and to examine the interdependence of the floc concentrations with regard to the desorption coefficient values. Nevertheless, the present form of the model can be used to investigate the influence of the reactor design elements on the effectiveness of the EC process.

\section{References}

[1] Chen, G. 2003: Electrochemical technologies in wastewater treatment, Sep. Purif. Technol., 38 (1), pp. 1-31, https://doi.org/10.1016/j.seppur.2003.10.006

[2] Abuzaid, N.S.; Bukhari, A.; Al-Hamouz, A. 2002: Ground water coagulation using soluble stainless steel electrodes, Adv. Environ. Res., 6 (3), pp. 325-333, https://doi.org/10.1016/S1093-0191(01)00065-X

[3] Vlyssides, A.G.; Karlis, P.K.; Rori, N.; Zopras, A.A. 2002: Electrochemical treatment in relation to pH of domestic wastewater using Ti/Pt electrodes, J. Hazard. Mater., 95 (1-2), pp. 215-226, https://doi.org/10.1016/S0304-3894(02)00143-7

[4] Bukhari, A.A; Abuzaid, N.S.; Abdulappa, M.K.; Esa, M.H. 1999: Pre-Treatment of Domestic Wastewater in an Electrochemical Cell, The Fifth Engineering Conference, 3, pp. 293-301.

[5] Feng, C.; Sugiura, N.; Shimada, S.; Maekawa, T. 2003: Development of a high performance electrochemical wastewater treatment system, J. Hazard. Mater., 103 (1-2), pp. 65-78, https://doi.org/10.1016/S03043894(03)00222-X

[6] Lin, S.H.; Wu, C.L. 1996: Electrochemical removal of nitrite and ammonia for aquaculture, Wat. Res., 30 (3), pp. 715-721, https://doi.org/10.1016/0043-1354(95)00208-1 
[7] Lee, J.; Lee, K.; Hong, H.S.; Kim, H.K.; Lee, H.B.; Lim, H.J. 2002: Residual chlorine distribution and disinfection during electrochemical removal of dilute ammonia from an aqueous solution, J. Chem. Eng. Jpn., 35 (3), pp. 285-289, https://doi.org/10.1252/jcej.35.285

[8] Lin, S.H.; Wu. C.L. 1997: Electrochemical nitrite and ammonia oxidation in sea water, J. Environ. Sci. Health, 32 (8), pp. 2125-2138, https://doi.org/10.1080/10934529709376672

[9] Kobya, M.; Can, O.T.; Bayramoglu, M. 2003: Treatment of textile wastewater by electrocoagulation using iron and aluminum electrodes, J. Hazard. Mater., 100 (1-3), pp. 163-178, https://doi.org/10.1016/S03043894(03)00102-X

[10] Ghanbari, F.; Moradi, M.; Eslami, A., Emamjomeh, M.M. 2014: Electrocoagulation/Flotation of Textile Wastewater with Simultaneous Application of Aluminum and Iron as Anode, Environ. Process., 1 (4), pp. 447-457, https://doi.org/10.1007/s40710-014-0029-3

[11] Mollah, M.Y.A.; Schennach, R.; Parga, J.R.; Cocke, D.L. 2001: Electrocoagulation (EC) -science and application, J. Hazard. Mater. B, 84 (1), pp. 29-41, https://doi.org/10.1016/S0304-3894(01)00176-5

[12] Prieto-García, F.; Callejas-Hernández, J.; Prieto-Méndez, J., Marmolejo-Santillán, Y. 2017: Electrocoagulation of whey acids: anode and cathode materials, electroactive area and polarization curves, J. Electrochem. Sci. Eng., 7 (2), pp. 89-101, https://doi.org/10.5599/jese.381

[13] Benefield, L.D.; Judkins, J.F.; Weand, B.L. 1982: Process chemistry for water and wastewater treatment, Prentice-Hall, Englewood Cliffs, NJ, 189 pp.

[14] Krstajic, N.; Nakic, V. 1987: Hypochlorite production. I. A model of the cathodic reactions, J. Appl. Electrochem., 17 (1), pp. 77-81.

[15] Lončar, G.; Matković, M.; Andročec, V. 2010: Numerička analiza pronosa efluenta iz podmorskog ispusta, Hrvatske vode, 18 (71), pp. 1-12.

[16] Ferziger, J.H. 1987: Simulation of Incompressible Turbulent Flows, J. Comp. Physics, 69 (1), pp. 1-48, https://doi.org/10.1016/0021-9991(87)90154-9

[17] Rodi, W. 1993: Turbulence Models and Their Application in Hydraulics - A State of the Art Review, IAHR Monographs, CRC Press, $124 \mathrm{pp}$.

[18] Smagorinsky, J. 1993: Some historical remarks on the use of nonlinear viscosities, In: Large eddy simulations of complex engineering and geophysical flows (B. Galperin and S. Orszag Eds.), Cambridge Univ. Press, 1993, pp. 3-36.

[19] Chorin, A.J. 1967: A Numerical Method for Solving Incompressible Viscous Flow Problems, J. Comp. Physics, 2 (1), pp. 12-26, https://doi.org/10.1016/0021-9991(67)90037-X

[20] Rasmussen, E. B. 1993: Three Dimensional Hydrodynamic models, In: Abbott, M.B. and Price, N.A. (eds), Coastal, Estuarial and Harbour Engineer's Reference Book, Chapman and Hall, London, pp. 109-116.

[21] Casulli, V. 1999: A Semi-Implicit Finite Difference Method for Non-Hydrostatic, Free-Surface Flows, Int. J. Numer. Meth. Fluids, 30, pp. 425-440, https://doi.org/10.1002/(SICI)1097-0363(19990630)30:4<425::AIDFLD847>3.0.CO;2-D

[22] Abbott, M.B.; Basco, D.R. 1989: Computational Fluid Dynamics, an Introduction for Engineers, Longman Scientific \& Technical, $425 \mathrm{pp}$.

[23] Richtmeyer, R.D.; Morton, K.W. 1994: Difference Methods for Initial-Value Problems, Krieger publishing company, $420 \mathrm{pp}$.

[24] Vested, H.J.; Justesen, P.; Ekebjærg, L. 1992: Advection-Dispersion Modelling in Three Dimensions, Appl. Math. Modell., 16 (10), pp. 506-519, https://doi.org/10.1016/0307-904X(92)90001-J

[25] Gross, E.S.; Bonaventura, L.; Rosatti, G. 2002: Consistency with Continuity in Conservative Advective Schemes for Free Surface Models, Int. J. Numer. Meth. Fluids, 38, pp. 307-327, https://doi.org/10.1002/fld.222

[26] Emamjomeh, M.; Sivakumar, M. 2005: Electrocoagulation (EC) technology for nitrate removal, In N. Khanna (Eds.), Environmental Postgrad Conference, Environmental change: Making it Happen, Australia: School Civil \& Chemical Engineering, RMIT, pp. 1-8.

[27] Emamjomeh, M.M.; Sivakumar, M. 2009: Denitrification using a monopolar electrocoagulation / flotation (ECF) process, J. Environ. Manage., 91 (2), pp. 516-522, https://doi.org/10.1016/i.jenvman.2009.09.020

Lončar, G, Halkijević, I, Posavčić, H, Ban, I 
[28] Hakizimana, J.N.; Gourich, B.; Chafi, M.; Stiriba, Y.; Vial, C.; Drogui, P.; Naja, J. 2017: Electrocoagulation process in water treatment: A review of electrocoagulation modeling approaches, Desalination, 404, pp. 121, https://doi.org/10.1016/i.desal.2016.10.011

[29] Sasson, M.B.; Calmano, W.; Adin, A. 2009: Iron-oxidation processes in an electroflocculation (electrocoagulation) cell, J. Hazard. Mater., 171 (1-3), pp. 704-709, https://doi.org/10.1016/i.jhazmat.2009.06.057

[30] Lai, C.L.; Lin, S.H. 2004: Treatment of chemical mechanical polishing wastewater by electrocoagulation: system performances and sludge settling characteristics, Chemosphere, 54 (3), pp. 235-242, https://doi.org/10.1016/i.chemosphere.2003.08.014

[31] Buerge, I.J.; Hug, S.J. 1997: Kinetics and pH dependence of chromium(VI) reduction by iron(II), Environ. Sci. Technol., 31 (5), pp. 1426-1432, https://doi.org/10.1897/04-238R.1

[32] He, Y.T.; Chen, C.C.; Traina, S.J. 2004: Inhibited $\mathrm{Cr}(\mathrm{VI})$ reduction by aqueous $\mathrm{Fe}(\mathrm{II})$ under hyperalkaline conditions, Environ. Sci. Technol., 38 (21), pp. 5535-5539, https://www.doi.org/10.1021/es049809s

Please cite this article as:

Lončar, G, Halkijević, I, Posavčić, H, Ban, I: Modeling total-nitrogen dynamics during electrocoagulation process with stainless-steel electrodes, Electronic Journal of the Faculty of Civil Engineering Osijek-e-GFOS, 16, pp. 1123, https://doi.org/10.13167/2018.16.2

Lončar, G, Halkijević, I, Posavčić, H, Ban, I 